Prace Filologiczne. Literaturoznawstwo 10(13) 2020

ISSN 2084-6045

e-ISSN 2658-2503

Creative Commons: Uznanie autorstwa 3.0 PL (CC BY)

DOI: $10.32798 /$ pflit.570

\title{
MICKIEWICZ UKRYTY ZA SŁOWACKIM? NOTA O TRÓJ-ANTAGONIZMIE WIESZCZÓW W PSALMIE ŻALU KRASIŃSKIEGO*
}

\author{
Mickiewicz Hidden behind Słowacki? \\ A Note about Tri-Antagonism between the Bards \\ in Krasiński's Psalm żalu [Psalm of Sorrow]
}

\author{
JERZY FIEĆKO \\ Uniwersytet Adama Mickiewicza w Poznaniu, Polska \\ E-mail: fiecko@amu.edu.pl \\ ORCID: 0000-0002-3678-7189
}

\begin{abstract}
The author, describing ideological polemics conducted between three most important Polish Romantic poets, modifies the notion of the "antagonism between the bards" (typically reserved for the dispute between Słowacki and Mickiewicz) by proposing the concept of "tri-antagonism". The matter is explained on the example of an analysis of conceptual senses (political, religious, historiosophical) inscribed in Psalm żalu [Psalm of Sorrow], a work by Krasiński from the period of the Spring of Nations (1848), which was commonly and rightly interpreted as Krasiński's (an opponent of revolution) last word in a dispute with Słowacki (who proclaimed the idea of the "Spirit - the Eternal Revolutionary"). The author puts forward a thesis that Mickiewicz with whom Krasiński led a dramatic dispute in Rome in 1848 over the Spring of Nations and the direction of the actions of the Polish community - is also the hidden negative hero of the work. Krasiński referred to this dispute in detail and in a very subjective way in letters to people close to him (including his lover, Delfina Potocka, and the philosopher August Cieszkowski). The author of this article shows that the arguments used by Krasiński in his polemic have been repeated in the Psalm of Sorrow and that in the negative portrait of the revolutionary "we" he included the features and thoughts attributed in those letters to Mickiewicz. Thus, the author argues, the dispute between Mickiewicz and Krasiński in 1848 should be regarded as a key element in the genesis of the analysed work.
\end{abstract}

Keywords: antagonism between the bards, romantics and revolution, Spring of Nations, Adam Mickiewicz, Zygmunt Krasiński, Juliusz Słowacki

*Publikacja artykułu dofinansowana przez Uniwersytet Warszawski. 


\section{Streszczenie}

Autor, opisując polemiki ideowe prowadzone przez trzech najważniejszych polskich poetów romantycznych, modyfikuje pojęcie ,antagonizmu wieszczów” (zarezerwowane zasadniczo dla sporu Słowackiego z Mickiewiczem), proponując koncepcję „trój-antagonizmu”. Rzecz objaśniona jest na przykładzie analizy sensów myślowych (polityczno-religijno-historiozoficznych) wpisanych w Psalm żalu, utwór Krasińskiego z okresu Wiosny Ludów (1848), który powszechnie i słusznie interpretowano jako ostatnie słowo Krasińskiego (przeciwnika rewolucji) w sporze ze Słowackim (głoszącym ideę „Ducha - Wiecznego rewolucjonisty”). Autor stawia tezę, że ukrytym bohaterem negatywnym utworu jest także Mickiewicz, z którym Krasiński wiódł w Rzymie w 1848 roku dramatyczny spór o Wiosnę Ludów i kierunek działania polskiej wspólnoty. Spór ten Krasiński referował szczegółowo i w sposób bardzo subiektywny w listach do bliskich mu osób (m.in. kochanki Delfiny Potockiej i filozofa Augusta Cieszkowskiego). Autor dowodzi, że argumenty użyte przez Krasińskiego w tej polemice powtórzone zostały w Psalmie żalu oraz że w negatywny portret rewolucyjnego „my” włączył cechy i myśli przypisane w tychże listach Mickiewiczowi. Tym samym, dowodzi autor, spór Mickiewicza i Krasińskiego z 1848 roku uznać należy za kluczowy element genezy tego utworu.

Słowa kluczowe: antagonizm wieszczów, romantycy i rewolucja, Wiosna Ludów, Adam Mickiewicz, Zygmunt Krasiński, Juliusz Słowacki

1.

Adama Mickiewicza w Psalmie żalu Bezimienny wieszcz w sposób bezpośredni nie przywołał; otwarcie ostrze polemiki skierował ku Słowackiemu (choć i jego nazwisko tam nie pada). Na tej też konfrontacji badacze dotąd skupiali swoją uwagę. Nie ulega jednak dla mnie wątpliwości, że geneza tego utworu związana jest także z dramatycznym starciem między Krasińskim i Mickiewiczem, jakie miało miejsce w Rzymie w marcu i kwietniu 1848 roku. Dlatego też uzasadnione są pytania: czy echo tego wydarzenia odbija się w najważniejszej w okresie Wiosny Ludów poetycko-ideowej deklaracji psalmisty? czy może jest to także próba poetyckiej odpowiedzi Mickiewiczowi, której sens rozumieli nieliczni świadkowie ich burzliwych dyskusji? czy to Mickiewicz jest drugim głównym (choć ukrytym dla postronnych odbiorców), po Słowackim, polemicznym adresatem tego utworu, a dzieło to stanowiło próbę zwycięskiego (w mniemaniu autora i jego zwolenników) zamknięcia trój-antagonistycznego agonu wieszczów?

Zwrotu „trój-antagonizm” używam nieprzypadkowo, bowiem niezależnie od wzajemnych fascynacji, przyjaźni i szczególnego rodzaju miłości („bom go kochał”, napisze Krasiński na wieść o śmierci Mickiewicza w liście do Cieszkowskiego ${ }^{1}$ )

${ }^{1}$ Do Cieszkowskiego 6 grudnia 1855 roku Krasiński napisał pamiętne słowa: „Arcysmutna wiadomość! Głazem grobowym przycisnęła mi serce, bom go kochał - i ducha, bo to był choć pęknięty może, ale zawszeż wielki, olbrzymi filar wśród podtrzymujących, rzadkich już i pękniętych wszystkich, nasze sklepienie"; Z. Krasiński, Listy do Augusta Cieszkowskiego, Edwarda Jaroszyńskiego, Bronistawa Trentowskiego, oprac. Z. Sudolski, t. 1, Warszawa 1988, s. 704. 
łączących te osoby, każdy z każdym zarazem wchodził w zasadniczy i długotrwały spór ideowy i te spory, o fundamentalne kwestie dla ówczesnej (i dzisiejszej) polskiej tożsamości, pomiędzy tymi intelektualistami uznać trzeba za jedno z najważniejszych wydarzeń w obszarze polskiej myśli tamtego czasu. Dzieje i sensy tych polemik - z osobna: Mickiewicza ze Słowackim, Słowackiego z Krasińskim, wreszcie Krasińskiego z Mickiewiczem - w tradycji badawczej rozpatrzono już dość gruntownie i nie ma powodu ${ }^{2}$, by je tu szczegółowo powtarzać, chciałbym jednak dopisać przyczynek do jednego z finalnych gestów w tej, jak niektórzy określają konflikt wieszczów z 1848 roku, „gigantomachii””. Chodzi mi o ukryty we wspomnianym tekście, z polemiczną intencją nakreślony, atak na Mickiewicza, który wpisany został po części w konterfekt samego Słowackiego i przede wszystkim w zbiorowe ujęcie rewolucjonistów; atak, którego obecności domyślać się mógł wówczas wąski krąg odbiorców: świadkowie rzymskich potyczek obu adwersarzy (m.in. Eliza Krasińska, Stanisław Małachowski, Cyprian Norwid), odbiorcy listów hrabiego z 1848 roku, w których opisywał swoje pojedynki z Mickiewiczem (m.in. Delfina Potocka, August Cieszkowski, Konstanty Gaszyński, Adam Sołtan) oraz sam Mickiewicz. By zarys tej batalii w psalmie zobaczyć, trzeba wyłuskać z systemu oskarżeń adresowanych do Słowackiego i rewolucyjnego świata te, które Krasiński z pewnością wcześniej, w pierwszej połowie tego roku, skierował wprost do Mickiewicza (dowodem jedyny list autora Irydiona do starszego wieszcza z lipca 1848 roku, któremu

\footnotetext{
${ }^{2} \mathrm{~W}$ badaniach nad polemikami romantyków szczególne znaczenie, jako dzieło swoiście założycielskie, ma oczywiście monografia Manfreda Kridla pt. Antagonizm wieszczów. Rzecz o stosunku Stowackiego do Mickiewicza (Warszawa 1925), w której obu polemistów autor przedstawił jako władców „nad państwem ducha polskiego” i zarazem spór ten uznał za najważniejszy spośród wszystkich sporów polskich romantyków. Znakomite analizy konfliktu Słowackiego z Krasińskim zawierają m.in. studia Z. Sudolskiego (Stowacki w oczach Krasińskiego. Z dziejów wzajemnych kontaktów, „Rocznik Towarzystwa Literackiego im. Adama Mickiewicza” 1979/1980, s. 123-137), A. Kowalczykowej (Słowacki, Warszawa 1994, s. 417-425), M. Janion (Dialektyka historii w polemice między Stowackim i Krasińskim, w: eadem, Prace wybrane, red. M. Czermińska, t. 2, Kraków 2000, s. 298-363) czy E. Szczeglackiej (Romantyczny homo legens. Zygmunt Krasiński jako czytelnik polskich poetów, Warszawa 2003). Ostatnia książka spośród tu wymienionych zawiera także wiele ważnych spostrzeżeń na temat związków Mickiewicz-Krasiński; polemiki między tymi dwoma pisarzami opisywali m.in. J. Kleiner (Zygmunt Krasiński. Dzieje myśli, Lwów 1912), J. Kallenbach (Towianizm na tle historycznym, Kraków 1924), W. Weintraub (Mickiewicz-Bakunin, „Kultura Paryska” 1949, nr 8), E. Bieńkowska (Rzym 1848, „Znak” 1974, nr 10), Z. Sudolski (m.in. Zygmunt Krasiński, Warszawa 1974), A. Kubale (Dramat bólu istnienia w listach Zygmunta Krasińskiego, Gdańsk 1997), A. Witkowska (Mickiewicz. Stowo $i$ czyn, wyd. 4 zmienione, Warszawa 1998), G. Tomaszewska (Mickiewicz - Krasiński. O wyobraźni utopijnej i katastroficznej, Gdańsk 2001). Relacji między tymi pisarzami poświęciłem monografię Krasiński przeciw Mickiewiczowi. Najważniejszy spór romantyków (Poznań 2011). Tam po raz pierwszy wzmiankowałem o inspiracyjnym znaczeniu polemiki rzymskiej dla genezy Psalmu żalu.

${ }^{3}$ Vide W. Karpiński, Dalekie i bliskie, „Twórczość” 1976, nr 5, s. 135-139.
} 
tu poświęcić trzeba będzie trochę uwagi) lub skierował prawdopodobnie, o czym wiadomo z jego własnych relacji epistolarnych do innych adresatów, relacji, których stopnia prawdomówności precyzyjnie oszacować się nie da. Powtarzając owe zarzuty w Psalmie żalu liczył zapewne, że Mickiewicz polemiczny przekaz zrozumie i swój ukryty portret zobaczy.

2.

Krasiński w prozatorskiej przedmowie jako główną przyczynę napisania Psalmu żalu w 1848 roku wskazał potrzebę odpowiedzi na utwór jeszcze nieopublikowany, który znał z odpisu (czy spodziewał się, że tekst ten niebawem zostanie ogłoszony bez zgody autora, nie wiadomo) - mowa oczywiście o Odpowiedzi na „Psalmy przyszłości” Spirydionowi Prawdzickiemu. Tekst ten został napisany przez Słowackiego przed rabacją galicyjską i zawiera błyskotliwą polemikę z psalmowym cyklem Krasińskiego, wydanym w Paryżu w 1845 roku. Zastanawia dwuznaczność całej sytuacji: oto czytelnik wymowę nieznanego szerszemu ogółowi tekstu Słowackiego (który nie zostaje zresztą wymieniony z nazwiska) poznawał z omówienia polemisty w owym wstępie. Omówienie to jest co prawda dość rzetelne i docenia wartość poetycką utworu ${ }^{4}$, ale przecież jednocześnie streszcza jego przesłanie w sposób, który ułatwiał w samym psalmie rozprawę z ideami nieznanego dzieła. Można nabrać podejrzeń, czy ten jawny chwyt polemiczny nie był swego rodzaju pretekstem (i kamuflażem) do podjęcia polemiki szerszej, kierowanej ku innym, dużo bardziej aktywnym politycznie w dobie Wiosny Ludów personom aniżeli poeta, o którym Krasiński nie tak dawno po lekturze I rapsodu Króla-Ducha wydał osąd, że zabrnął tak bardzo w mistyczne zawiłości, że popadł w myślową sprzeczność i śmieszność 5 . I którego od dawna nie traktował jako równoprawnego partnera w publicznym dyskursie.

${ }^{4}$ „Ta pieśń w rękopiśmie, jedna z przedziwności języka polskiego, brzmiąca cudownymi wdzięki, a głębokiego mistycyzmu piętnem naznaczona, wyobrazicielką niektórych dążności i myśli, krążących po widnokręgach umysłowych Epoki naszej”; Z. Krasiński, Dzieła literackie, oprac. P. Hertz, t. 1, Warszawa 1973, s. 227.

${ }^{5}$ "Czytałem wczoraj Króla-Ducha” - pisał Krasiński do Delfiny Potockiej 10-11 lutego 1847 r. - „wolałbym był logikę Heglowską, jaśniejsza, choć nic na ziemi zawilej i niezrozumialej napisanego nie masz, jednak twierdzę, że zrozumialsza. A to strach, na 500 strofach, jeślim zrozumiał 20, to już wiele, i nie śmiałbym ręczyć. Są słowa ślicznie brzmiące, są obrazy ślicznie pojęte, które nie mogą wypłynąć na wierzch i w oczy cię uderzyć. Dopiero musisz rozumem je rozbierać, zupełnie tak samo, jako logikę filozoficzną, łamać łeb, aż boli! Biedny Słow[acki]. Kilka zaś strof prześlicznych, przepysznych, ale reszta bez związku, początku, końca, ciągu. Czasem jakby pijany pisał, to znów jakby wariat, to znów jakby kpiarz z czytelnika, który same brał wyrazy na oślep i kalejdoskopicznie je rzucał, a co wypadło, wydrukował. Zgoła nic, a nic nie zrozumiałem, żadnego szczegółu, myśl ogólną tylko metempsychozy pojąłem”; Z. Krasiński, Listy do Delfiny Potockiej, oprac. Z. Sudolski, t. 3, Warszawa 1975, s. 262. 
Relacja Krasiński-Słowacki w tradycji badawczej opisywana była wielokrotnie i dość powszechnie przyjmuje się, że weszła ona w fazę krytyczną w połowie lat czterdziestych, choć moim zdaniem hrabia zaczął mocno dystansować się wobec Słowackiego już wcześniej, po lekturze Beniowskiego w 1841 roku$^{6}$. Krasiński na przełomie lat trzydziestych i czterdziestych przeprowadził kampanię na rzecz uznania w Słowackim wybitnego artysty, w ramach której wykorzystywał listy do przyjaciół (niewątpliwie przeznaczone też do towarzyskiego kolportażu), a przede wszystkim opublikował w poznańskim „Tygodniku Literackim” głośny esej pt. Kilka słów o Juliuszu Słowackim, w którym przypisał mu rolę „siły odśrodkowej" polskiej literatury, mistrza stylu i języka stanowiącego konieczne dopełnienie dla Mickiewicza (,siły dośrodkowej”). Jednocześnie w listach do Słowackiego (a także w samym eseju) próbował skłonić starszego poetę do wypracowania spoistej myśli, klarownego projektu filozoficzno-historiozoficznego, bez której być wieszczem w pełnym znaczeniu nie można ${ }^{7}$. Lektura poematu dygresyjnego uświadomiła Krasińskiemu, że niepowodzeniem zakończyła się jego próba wymuszenia na Słowackim zwrotu w stronę poezji, która zespalałaby styl i myśl wedle reguł bliskich jego własnym wyobrażeniom, bez skrywania się za zasłoną romantycznej ironii. Od tego czasu datuje się coraz większa rezerwa w jego kontaktach ze Słowackim. Krasiński bowiem od początku ich relację starał się oprzeć wyłącznie na podstawie intelektualnej, jako przyjaźń pisarzy, nie widział natomiast w Juliuszu kandydata do tego typu męskiej przyjaźni, jaką praktykował z Gaszyńskim, Małachowskim, Sołtanem czy Cieszkowskim, którym powierzał sprawy najbardziej intymne i osobiste. Słowackiego tuż po poznaniu w 1836 roku hrabia uznał za człowieka naznaczonego niezwykłą wyobraźnią, ale życiowo i psychologicznie niedojrzałego i osądu tego bodaj nigdy nie zmienił ${ }^{8}$. W 1843 roku Słowacki podjął epistolarną próbę przyciągnięcia Krasińskiego

${ }^{6}$ Szerzej uzasadniłem tę tezę w szkicu pt. Słowacki wedtug Krasińskiego, w: Jaki Słowacki? Studia $i$ szkice $w$ dwusetna rocznicę urodzin poety, red. E. Grzęda, M. Ursel, Wrocław 2012, s. 231-242.

${ }^{7}$ Przykład tego rodzaju namów zawiera choćby list Krasińskiego z 23 lutego 1840 r., w którym pisał do Słowackiego: „Każdy wielki poeta jest niejako i objawicielem, tj., że nieobjawione wyrywa z szarej przestrzeni przedstworzenia i przenosi w jaśń świetlaną stworzenia i rzeczywistości. [...] Gdybym miał i ja nareszcie jednę Ci uwagę uczynić, to jedną tylko bym uczynił - granit rzuć pod Twoje tęcze! Tęcza, gdy łukiem się zakala po niebie, winna stopy śliczne oprzeć na podstawie granitowej"; Z. Krasiński, Listy do różnych adresatów, oprac. Z. Sudolski, t. 1, Warszawa 1991, s. $444,446-447$.

${ }^{8}$ Pierwszą charakterystykę Słowackiego sporządził Krasiński w liście do Gaszyńskiego z 20 listopada 1836 r.: „Dziwny to kontrast w tym człowieku: awanturniczy wyobraźnią, tchórz zaś nerwami i całym ciałem. [...] Tę uwagę o Julku schowaj dla siebie. Ogadywać bym go nie chciał, tak jak bym w żadnym przypadku także i liczyć na niego nie chciał. Z tymi istotami obchodzić się trzeba jak z morzem, jak z elektrycznością: zważać ich objawienia i dziwić się im, jeśli silne, żadnej zaś nadziei ni rachuby na nich nie pokładać”; Z. Krasiński, Listy do Konstantego Gaszyńskiego, oprac. Z. Sudolski, Warszawa 1971, s. 136. 
do towianizmu, ale autor Irydiona miał na temat tego ruchu już wyrobione zdanie i dość stanowczo uchylił się od dłuższej dyskusji na temat tej kwestii ${ }^{9}$ (choć towianizmem jako specyficzną myślą religijną był żywo zainteresowany i przez pewien czas uważał, że są w niej oryginalne pierwiastki - wniesione przez Mickiewicza, w którym widział właściwego twórce „,doktryny”). Dwa lata później Słowacki napisał Odpowiedź na „Psalmy przyszłości”, która zawiera radykalną polemikę polityczno-historiozoficzną z konserwatywno-mesjanistyczną, z ducha solidarystyczną i etnocentryczną („Jeden tylko, jeden cud: / Z Szlachtą polską - polski Lud" - kluczowy passus z Psalmu miłości), antyrewolucyjną wreszcie myślą psalmów Krasińskiego. Niektórzy badacze w polemice Słowackiego widzieli niekonsekwencję $\mathrm{w}$ tym, że $\mathrm{z}$ jednej strony wykpiwał lęk przed rewolucją i rozbiciem wspólnoty narodowej jako fałszywy fantazmat „syna szlacheckiego", a z drugiej wieścił nieuchronność i konieczność wielkich kataklizmów dziejowych jako czynnik zgodny z wolą Opatrzności, eksponował „mękę ciał” jako konieczny element wielkiego procesu dziejowego. Rację ma jednak Maria Janion, która w precyzyjnym rozbiorze tego sporu słusznie zauważyła, że Słowacki błędu Krasińskiego

nie upatrywał w przewidywaniu, że kataklizm społeczny obali stary ład. Akcent padał na co innego. Słowacki dostrzegał napiętnowania godne tchórzostwo przede wszystkim w samym zanegowaniu przez Krasińskiego postępowego znaczenia epok burzących, w niedocenianiu roli gniewnego ludu jako narzędzia wyższego mechanizmu świata. Oszczerstwem w rozumieniu Słowackiego było mówienie o „rzezi” i „mordzie”, było szukanie analogii wśród powszechnie wówczas oszkalowanych przywódców Rewolucji Francuskiej dla tego, co on uważał za „wdarcie się Ducha”, za gwarancję Królestwa Bożego, choćby przynieść miało „ludów zatracenie”10.

Krasiński zresztą bezbłędnie zrozumiał, że centralny punkt wywodu Słowackiego znajduje się w strofie mówiącej o Duchu dziejów jako „Wiecznym Rewolucjoniście"11, w polemice jednak nie omieszkał wykorzystać faktu, że rabacja podała mu argument potwierdzający zasadność lęków przed żywiołem ludowej zemsty, co w jego rozumieniu rozstrzygało kwestię, który z polemistów lepiej rozumie istotę ducha dziejów.

\footnotetext{
${ }^{9}$ Znakomitą analizę różnic religijno-historiozoficznych ujawnionych w korespondencji Krasińskiego i Słowackiego z 1843 roku zawiera cytowane wcześniej studium Marii Janion.

${ }^{10}$ M. Janion, op. cit., s. 346.

${ }^{11}$ Chodzi przede wszystkim o następujący fragment: „Więc się bój - bo Duch się wdziera,/ Już podnosi góry, wieże. / »Staby«, mówisz, »rzeź wybiera « - / A czy wiesz, co on wybierze?.../ Może ludów zatracenie - / Może nam przyniesie w dłoni / Komet wichry i płomienie, / W których drży król - matka roni - / Działa, wozy, hufce, konie / Ogień pali - ziemia chłonie... / A nikt z ruin nie korzysta, / Jeno wszczynający ruch, / Wieczny Rewolucjonista, / Pod męką ciał leżący Duch"; J. Słowacki, Dzieła wszystkie, red. J. Kleiner, t. 7, Wrocław 1952, s. 264. Krasiński we wstępie do Psalmu żalu właśnie na fragment głoszący ideę Ducha - Wiecznego Rewolucjonisty położył mocny akcent.
} 
Bezpośrednia polemika ze Słowackim wypełnia przede wszystkim pierwszą część Psalmu żalu i stanowi dowód nie byle jakich umiejętności Krasińskiego w sztuce argumentacji, w której zresztą nie stronił od używania chwytów rodem z erystyki (ataki ad personam, które pojawiły się też w Odpowiedzi Słowackiego, bo taki charakter miały zarzut tchórzostwa i sugestia, że za konserwatywną ideologią skrywa się wygodna przynależność do uprzywilejowanej warstwy). Krasiński, odwołując się do posądzenia o tchórzostwo, na początku wywodu przyznał, że czuje lęk przed rewolucją, ale nie jako arystokrata i „syn szlachecki”, lecz jako prawy Polak przywiązany do tradycji rycerskiej, który wie, że krwawy konflikt społeczny rozkłada narodową wspólnotę i niszczy jej duszę. Odparowawszy ten zarzut, uderzył hrabia w profetyczne kompetencje Słowackiego, w krótkim a spektakularnym akapicie wiążąc ocenę rabacji (z dodatkiem stereotypów na temat niemieckiej podstępności i żydowskiej wrogości do szlachty i polskości) z krytyką lewicy emigracyjnej („wersalskie dzieci”) i ośmieszeniem duchowości (i osobowości) adwersarza - a więc kwestie niekoniecznie w sposób naturalny korespondujące ze sobą:

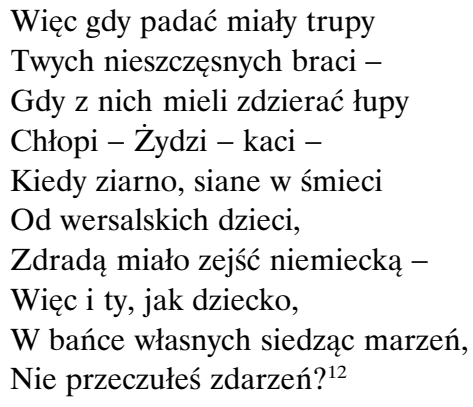

W ujęciu Krasińskiego niezdolność konkurenta do przewidzenia domowego rozlewu krwi była nie tylko przejawem i świadectwem braku profetycznych (i politycznych) zdolności, ale przede wszystkim oznaczała kompromitację historiozoficznej projekcji Ducha dziejów jako kreatora procesu wymagającego gwałtownych rewolucji oraz cierpień jednostek i narodowych wspólnot. Tego rodzaju myślenie - ostrzegał - czyni z Julinicza (pod takim imieniem wprowadził Słowackiego, jako opętanego wieszczka rewolucji, w obręb niedokończonej I części Nie-Boskiej komedii) proroka niechrześcijańskiego, bez mała zdrajcę Boga (bo lekceważącego Jego oczywiste nakazy) i narzędzie zła, spadkobierce zbrodni Attyli, Inkwizycji i Robespierre'a, wreszcie mimowolnego sojusznika caryzmu, który europejski zamęt rewolucyjny wykorzystuje do narzucenia światu swojej dominacji. Innymi słowy - przypiął Słowackiemu

\footnotetext{
${ }^{12}$ Z. Krasiński, Dzieła literackie, t. 1, s. 231.
} 
etykietki, którymi w tamtych latach oznaczał wszystkich swoich niekonserwatywnie zorientowanych oponentów, zwolenników rewolucji w szczególności, a więc Henryka Kamieńskiego, zaś w 1848 roku m.in. Karola Libelta i przede wszystkim - Mickiewicza.

Zarazem strategię diabolizacji Słowackiego przełamał ironią ośmieszenia, przypisując mu niedojrzałość, oderwanie od grozy dziejów, zanurzenie w świecie historiozoficznych fantazji, w którym gloryfikując przemoc i zbrodnię jako Boże narzędzia, jednym gestem rzuca się narody i warstwy społeczne na zatratę. Przywołując obraz dziecka siedzącego w „bańce własnych marzeń” (dziecka marzącego), zręcznie i złośliwie wykorzystał motyw zakodowany we wczesnej twórczości Słowackiego, zwłaszcza w Kordianie, gdzie był on znakiem pogrążenia w niemocy, w fantazmatach blokujących możliwość działania w realnym świecie. Zabieg „zdziecinnienia” Słowackiego posłużył zresztą zdjęciu z niego ciężaru winy za rabację. Tę Krasiński przypisał siłom mającym realny wpływ na ideologię i politykę, czyli pospołu lewicy emigracyjnej oraz austriackiemu zaborcy. Chwyt ten jednocześnie otwierał możliwość zaproszenia polemisty do kręgu idei i postaw w rozumieniu Krasińskiego prawdziwie dojrzałych i zgodnych z dziejotwórczą intencją Opatrzności. Nie było w tej ofercie elementów nowych - powtórzył jedynie idee zapisane już we wcześniejszych częściach psalmowego cyklu oraz w Przedświcie, włącznie z hasłami o nieprzedawnionym depozycie szlacheckiego przywództwa (w kontrze do tezy o duchowej i politycznej śmierci szlachty, ogłoszonej w Odpowiedzi), o konieczności przemiany (,przeanielenia”) duszy Ludu (zamiast podsuwania mu obrazów krwawych przemian, które pojmie jako wezwanie do zemsty), potrzebie ponadstanowej jedności oraz wyrzeczenia się rewolucyjnej przemocy w obrębie macierzystej wspólnoty. Profetyzmowi rewolucyjnemu przeciwstawił proroctwo miłości i pojednania, a wizji Ducha - Wiecznego Rewolucjonisty obraz Ducha Bożego działającego ewolucyjnie, który „płynie - a nie skacze”, „wschodzi - a nie spada”. Za Janion można powtórzyć, że „postępowi przez krew” przeciwstawił „organicystyczny rozwój"13.

Zabieg „zdziecinnienia” Słowackiego narzuca jeszcze jedną sugestię: że prowadzony w dalszych partiach psalmu bardzo serio spór ze światem rewolucji już nie do Słowackiego był adresowany, nie jego dotyczył, ale innych, aktywniej zanurzonych w działania i lepiej uosabiających owo rewolucyjne „my”, rewolucyjnego bohatera zbiorowego, do którego zwłaszcza w trzeciej części będzie przemawiał z gniewem, jakby ciągnąc dalej jakiś pozatekstowy dialog filozoficzny i polityczny zarazem ${ }^{14}$. Dla Krasińskiego w 1848 roku uosobieniem biesa

${ }^{13}$ M. Janion, op. cit., s. 359.

${ }^{14}$ Obszerny opis politycznych poglądów Krasińskiego zawiera rozprawa Andrzeja Fabianowskiego pt. Myśl polityczna Zygmunta Krasińskiego (Ciechanów 1991). 
rewolucji stał się rzymski Mickiewicz, a w listach ich ówczesną konfrontację przedstawiał jako starcie Henryka i Pankracego, dwóch rzeczywiście przewodnich duchów rozdartej wspólnoty ${ }^{15}$.

3.

System „mickiewiczowskich” aluzji, czytelnych dla wąskiego grona wtajemniczonych, odnaleźć można już w pierwszej partii Psalmu żalu, zdominowanej przez bezpośredni spór ze Słowackim. Krasiński określa w nim Słowackiego (choć nie wymienia jego nazwiska, więc otwiera pole domysłów) mianem „wieszcza starego” („Ależ, wieszczu - boś ty wiary / Dni zaprzeszłych - tyś wieszcz stary!”), co poprzez kontekst, naciągając sensy, zrozumieć można tak, iż owa starość wynika z ideowego przypisania się przeciwnika do odwiecznej rodziny politycznych zbrodniarzy, krwawych tyranów, symbolicznie reprezentowanych tu przez imiona Attyli i Robespierre'a. Ale zwrot „tyś wieszcz stary” prowokuje także pytanie o przynależność pokoleniową atakowanego, a w polskiej przestrzeni kulturowej w owym czasie takie miano naturalną koleją rzeczy wywoływało skojarzenia z Mickiewiczem, najstarszym spośród poetów wpisywanych w rodzącą się wtedy konstelację „trzech wieszczów”16. Co więcej, w listach z 1848 roku Krasiński, portretując pięćdziesięcioletniego Mickiewicza, przywoływał wątek starości (mającej emanować z jego sylwetki), który w opisie sceny ich rzymskiego pożegnania powiązał właśnie z tropem ,zdziecinnienia” - wtedy takie zestawienie przetestował po raz pierwszy: „Ściskał mnie do zaduszenia. Wyglądał na człowieka zupełnie przełamanego. Mówiłem mu jeszcze, by siał miłość, nienawiści nie krzewił. »Masz święte prawo tak mówić« - odrzekł i jeszcze ściskał mnie bardziej, jak dziecko, jak półobłąkaniec, jak starzec rozbity" ${ }^{\prime 17}$. Także poglądy i postawę rzymskiego adwersarza, zwłaszcza w listach do Potockiej i Cieszkowskiego, chętnie zestawiał ze spuścizną dawnych tyranów, przywołując figury „Dżengis-chana”, carów moskiewskich (w tym Iwana Groźnego i Piotra I) oraz rewolucyjnej Konwencji, czyli obracał się w kręgu tych samych skojarzeń historycznych, które uruchomi w Psalmie żalu (Attyla, Robespierre, Inkwizycja, Iwan Groźny).

Strategia polemiki z polskimi zwolennikami rewolucji w części trzeciej psalmu zawiera linię wywodu nasyconą paradoksami i zręcznymi manipulacjami

${ }^{15} \mathrm{O}$ rzymskim sporze Mickiewicza i Krasińskiego cenne spostrzeżenia odnaleźć można m.in. w studiach W. Weintrauba (op. cit.), E. Bieńkowskiej (op. cit.), A. Kubale („Z nadziei moich wygnany błakam się i tułam" czyli o rzymskich wydarzeniach 1848 roku, w: eadem, Dramat bólu istnienia..., s. 130-140), E. Szczeglackiej (1848. Mickiewicz i rewolucja w świetle listów, w: eadem, Romantyczny homo legens, s. 118-144).

${ }^{16}$ Dzieje kształtowania się mitu „trzech wieszczów” precyzyjnie zrekonstruował Henryk Markiewicz (Rodowód i losy mitu trzech wieszczów, w: Świadomość literatury. Rozprawy i szkice, Warszawa 1985, s. 180-224).

${ }^{17}$ Z. Krasiński, Listy do Delfiny Potockiej, t. 3, s. 805 (list z 10 kwietnia 1848 r.). 
charakterystycznymi wszakże dla ówczesnego stylu myślenia Krasińskiego - stylu, do którego także odwołał się w trakcie sporów rzymskich ze „starym wieszczem”. Najmłodszy z wieszczów przede wszystkim powiązał idee rewolucyjne z caryzmem (mongolizmem), na równi traktując je jako zdradę wobec boskiego Ducha dziejów - jako świadomy zamiar cofania historii wstecz - a także postawił tezę, że istnieje nieuchronny związek pomiędzy ideą braterstwa w teorii i mordem, zbrodnią w rewolucyjnej praktyce:

- Ze świętości Duch jednolit -

Ni mongolskich biczy,

Ni czerwonych Rzeczpospolit

W swe cuda nie wliczy!

Wolna tylko ludzka wola,

Gdy zła i nieszczera,

Taki tor obiera

I nim ziemskie brudzi pola!

Bo tak wolna, że aż zdolna

Drogi Boże same

Przepiekielnić w zguby jamę!

Bo tak wolna, że aż zdolna

$\mathrm{W}$ imieniu braterstwa

Rozsiewać morderstwa -

$\mathrm{W}$ imieniu nadziei

Świat wytrącić z swych kolei,

By bez wstępnych sił,

Ześlizgnął się po wiekach $\mathrm{w}$ tył ${ }^{18}$.

Każdy zatem - dowodził wieszcz konserwatywny - kto wzywa do rewolucji, choćby moralnie wzniosłej i czystej, odwołując się przy tym do religii chrześcijańskiej i osoby Chrystusa, w głębi ducha nosi znamię pychy, a stając się fałszywym prorokiem, zdrajcą ludzkości i ojczyzny, musi być (jest) gotów na rolę najpierw „kata dusz”, a potem „kata ciał”:

Powtarzacie: „Chryste! Chryste!”

A nie macie w sercu Jego -

Jakżeż Ducha wam świętego

Przejąć dobro wiekuiste?

$\mathrm{Z}$ was się każden nad odłogiem

Własnej próżni wspina Bogiem

Na paluszkach wzdętej pychy! -

I tak wy zwierzęciejecie. -

Bo kto sam się bóstwi w świecie,

${ }^{18}$ Z. Krasiński, Dzieła literackie, t. 1, s. 240. 
Ten na odwrót swego szału

Odczłowiecza się pomału -

[...]

Lub też dziki - sępny - chory -

Miasto widzeń - widzieć zmory,

Miasto natchnień - czuć wściekliznę

Będzie - zmąci wiary, dzieje,

Człowieczeństwo i ojczyznę,

Zwątp rozpaczy i nadzieję!

Wtedy śród błędów swych pędu

Wezwie drugich do obłędu -

Za każdym się krokiem

Przenazwie prorokiem -

Zbawicielem - Bożym Bratem:

I dusz wielu będzie katem!

Aż, nie wątpiąc, że się zbożył,

Że, jak Boga stwórcą znał,

Tak się stwórcą sam tu stworzył,

Coraz pełńszy własnych chwał,

Pocznie wierzyć jadowicie,

Że mu sługą - ludzkie życie:

Stanie się i katem ciał! ${ }^{19}$

Trudno nie postawić pytania, czyj portret personalny w owo zbiorowe, rewolucyjne „wy” wtłoczył Krasiński. Słowackiego? Cechy samoubóstwienia, wiary w prorockie powołanie i pewność zrozumienia Boga mógł Krasiński przypisać Słowackiemu; tak mniej więcej interpretował I rapsod Króla-Ducha i, szerzej, jego przeobrażenia duchowe w latach czterdziestych, w czym widział szkodliwy wpływ towianizmu. Ale nie tylko o Słowackim wyrażał wtedy takie opinie, a właściwie o Słowackim w listach wypowiadał się bardzo rzadko. I nie do Słowackiego pasuje teza o „skatowaniu” wielu dusz oraz wypracowaniu pozycji, z której, odwołując się do własnych idei religijnych, można przystąpić do roli „kata ciał”. Tak w 1848 roku Krasiński postrzegał Mickiewicza - jako innowatora religijnego (przybył do Rzymu, by bronić przed papieżem towianistycznej idei) i jako człowieka niepodległościowo-rewolucyjnego czynu, twórcę Legionu i autora Składu zasad, gorącego zwolennika „czerwonego sztandaru” i „czerwonych Rzeczpospolit". To prawda - nie tylko Mickiewicz w tamtym czasie łączył w działaniu idee niepodległościowe, religijne i rewolucyjne. Spośród najbardziej znanych wskazać można choćby Giuseppe Mazziniego (z którym w 1848 roku we Włoszech twórca Legionu współpracował). Jednak wszystkie wymienione w tym fragmencie psalmu elementy portretu rewolucjonisty wcześniej przypisał w licznych listach właśnie i tylko „panu Adamowi”.

\footnotetext{
${ }^{19}$ Ibidem, t. 1, s. 241-242.
} 
W przypisie przytaczam obszerną partię jedynego spośród znanych nam listów Krasińskiego do Mickiewicza jako świadectwo krytyki adresowanej wprost do starszego wieszcza ${ }^{20}$. Pominę tu sprawę skrajnej jednostronności widocznej w opisie czerwcowego powstania paryskiego, a właściwie buntu robotniczego, który był efektem załamania społecznej polityki rządu republikańskiego (22 czerwca Zgromadzenie ogłosiło decyzję o rozwiązaniu warsztatów narodowych, następnego dnia stanęły barykady) i przyniósł blisko 5 tysięcy ofiar, w ogromnej większości po stronie powstańców (wielu z nich rozstrzelano już po stłumieniu buntu). Pominę też zabieg przekłamywania faktów - arcybiskup Denis Affre, sympatyk Republiki, szanowany przez lud paryski, zginął nie z rąk buntowników, ale od zabłąkanej „kuli rządowej”21 . Z perspektywy psalmu znaczenie ma wyrażone w tym liście, ugruntowane przeświadczenie Krasińskiego, że Mickiewicz był i pozostał zwolennikiem krwawej rewolucji (owego „czerwonego

${ }^{20}$ Krasiński napisał ten list 1 lipca 1848 roku w Paryżu, tuż po brutalnym stłumieniu przez wojska generała Louisa Cavaignaca trzydniowej rewolucji paryskiej (23-26 czerwca 1848), w trakcie której śmierć poniósł (od kuli wojsk rządowych) arcybiskup Paryża Denis Auguste Affre, w chwili gdy na barykadzie namawiał republikańskich powstańców do zaniechania walki. Mickiewicz do Paryża wrócił już po tych wypadkach, 10 lipca: „Kiedyś nie wiedział wprzód, teraz po dniach czerwcowych dowiedziałeś się, Adamie, czego wyobrazicielem sztandar czerwony, za którym tak tęskniłeś w marcu. Raczej, zdaje się, nie chciałeś wiedzieć. Dziś chceszli, nie chceszli, musisz. Sam albowiem ten sztandar rzecz swoją wypowiedział swymi napisami światu, sam wystąpił przez czyn, rzucił się do mordu, łupieży, wszeteczeństwa, pragnął zniesienia nie onych rzeczy, co przemijalne i przemieniane, ale onych, co wiekuiste, tak na planecie tym, jak po wszystkich światach. Bluźnił bożym prawom, arcybiskupa zamordował. [...] Kwasem siarczanym, zatrutymi kulami, kłamstwem i zdradą, od piekła zapożyczonymi sposoby darł się - a do czego? Do rozkoszy episjerów, do zbytków, które przeklina, póki ich nie osiągnie. Takie dzieje czerwonego sztandaru, o którym takeś się ze mną sprzeczał. Upamiętaj się, człowiecze, i już nigdy nie powtarzaj, że takie czasy dziś i że Bóg samych łotrów dobiera do sprawy swojej. Takich czasów nigdy na świecie ni było, ni będzie. Bóg nie dobiera łotrów do sprawy swojej. Takich czasów nigdy na świecie ni było, ni będzie. Bóg nie dobiera łotrów do dzieł swoich, ale tak piękny, że choć łotry wmieszają się w sprawę ludzkości, on z ich szkaradzieństw jeszcze umie piękność jakąś wiekuistą wyratować, taki dobry i miłosierny, że choć łotry zwyciężą dnia pewnego, zwycięstwo samo ich gubi i zabija, a dobroć wiekuista w wyższe jeszcze okręgi świat porywa. Nie z łotrami trzyma więc Bóg, ale z ludzkością, którą stworzył przeciw łotrom, którzy się odstworzyli. Taka jest prawda, Adamie, mówiłem Ci ja w Rzymie. Teraz koniecznie uczułem sumienie na mnie wołające, bym Ci ją powtórzył. Podziękuj Bogu, żeś tu się nie znalazł podczas tych dni, bo byłbyś duszę swą aż na samo dno piekła strącił. Opatrzność i dane $\mathrm{Ci}$ od niej natchnienie wyratowały Cię. Podziemia Cię paryskie schwycić i wyzionąć ze siebie jako jedną z iskier swych nie zdołały, choć taki miał być los Twój. Dziękuj, dziękuj Bogu, byłbyś Polskę w sobie odzacnił, a nad zacność nic wyższego, a szałem mniemać, że może być świętość i sprawa Boża bez zacności. Wygraj mi pieśń bez dźwięków! Bóg Cię prowadź i błogosław, Bóg strzeż ducha Twego"; Z. Krasiński, Listy do różnych adresatów, t. 2, s. 207-208.

${ }^{21}$ J. Baszkiewicz, Historia Francji, Wrocław 1999, s. 442. O wydarzeniach paryskich vide m.in. J. Dautry, Historia rewolucji i kontrrewolucji we Francji w latach 1848-1851, Warszawa 1950; F. de Luna, The French Republic under Cavaignac, 1848, Princeton N.J. 1969; A. Liebfeld, Napoleon III, Warszawa 1979. 
sztandaru"), dlatego hrabia założył, że w Paryżu w czasie czerwcowego buntu stary wieszcz niechybnie znalazłby się na barykadach, co - w rozumieniu hrabiego - zniszczyłoby jego więź z polskością „zacną” (co z kolei znaczyło: z polskością odrzucającą ideę radykalnego czynu niepodległościowo-społecznego). Krasiński przypisał polemiście zamiar wciągania „łotrów” (Krasiński zapewne miał na myśli nie tyle przestępców i zbrodniarzy, co po prostu ludzi z nizin społecznych) w tryby rewolucji, podczas gdy Mickiewicz uważał, że lud - wielkie zbiorowości społeczne - powinien być zaangażowany w sposób podmiotowy w procesy dziejotwórcze i powinien uzyskać pełnię praw politycznych (czego świadectwem jest Skład zasad). Krasiński był w owym czasie tej idei, w swojej istocie republikańskiej i demokratycznej, stanowczo przeciwny. Znamienne jest, że hrabia nie dopytywał tu o losy formowanego na ziemi włoskiej Legionu, niepodległościowej przecież siły zbrojnej, w którego organizowanie i wspieranie Mickiewicz zaangażował wszystkie siły i dla którego zabiegał też o poparcie ze strony generała Louisa Cavaignaca, dyktatora i sprawcy pogromu czerwcowego, ale z punktu widzenia poety - przede wszystkim faktycznego lidera francuskiej polityki. Nie dopytywał nie tylko dlatego, że nie był zwolennikiem tego przedsięwzięcia (choć potajemnie wyłożył na Legion sporą sumę), ale z tego powodu, że Mickiewicz w jego wyobraźni zrósł się z ,czerwonym sztandarem”, chciał więc zrobić wszystko, by wieszcz wracający z Włoch do niespokojnego, podminowanego społecznymi konfliktami Paryża nie wszedł w bliskie związki z „paryskimi podziemiami” (w rzeczywistości po czerwcowej klęsce radykalna lewica przeżywała głęboki kryzys i w pewnym stopniu musiała zejść do podziemia, choć zachowała przyczółki w Zgromadzeniu). W III części Psalmu żalu rewolucjoniści, wyznawcy „czerwonego sztandaru”, sieją terror, używają „łotrów” i takimi się stają, sięgając po niecne środki („Kule strute - kwas siarczany - / Ludożercze bronie”), takie właśnie, o jakich mowa w tym liście. Wiele innych cech przypisanych Mickiewiczowi w listach z okresu Wiosny Ludów przeniknęło do psalmowej polemiki. Należy omówić tu kilka przykładów.

Najpierw aspekt religijny, czyli zarzuty fałszywego powoływania się na imię i spuściznę Chrystusa („Powtarzacie „Chryste! Chryste! / A nie macie w sercu Jego”), wchodzenia w rolę proroka (fałszywego) - „Bożego Brata”, który stał się „katem dusz”. Ten wątek ma ścisły związek z ówczesną krytyką towianizmu i Mickiewicza-towiańczyka. Krasiński, który w latach wcześniejszych nie bez zainteresowania śledził losy tego środowiska, a zwłaszcza z uwagą rozpatrywał wykuwaną w tym kręgu „doktrynę” religijną 22 , w roku 1848 niezwykle zaostrzył swój krytycyzm - dokonał wręcz swoistej „demonizacji” towianizmu, przypisując

${ }^{22}$ Cf. m.in. A. Kowalczykowa, Poglądy filozoficzne Zygmunta Krasińskiego, w: Polska myśl filozoficzna i społeczna, red. A. Walicki, t. 1, Warszawa 1973 (zwł. s. 328-330). 
mu, oczywiście błędnie, rozległe wpływy w europejskim świecie podziemnym. Krasiński od dawna przyjmował za pewnik, że w towianistycznym światku mają miejsce praktyki przypominające duchowy terror (stąd metafora „kata dusz”), a po spotkaniu z Mickiewiczem w Rzymie uznał, że ten wykorzystuje „mongolski pierwiastek w objawianiu Bożych prawd”, że stał się „Iwanem Groźnym w Nowej Jerozolimie”. „Chce świętych w szeregu stojących na kształt sołdatów, chce świętych musztry wyuczonych, chce świętych kierowanych przez sierżantów, oficerów, pułkowników. Śni mu się metoda moskiewska, a w Nowej Jerozolimie!’23 Dlatego zapewne wskazanie w Składzie zasad etyki chrześcijańskiej jako fundamentu moralnego przyszłej Polski (przy jednoczesnym równouprawnieniu wszystkich religii) autor Irydiona potraktował jako gest fałszywy, jako swego rodzaju zasłonę dla celów w swojej istocie terrorystycznych, rozbijających wspólnotę.

Kwestia druga, z poprzednią ściśle związana: gotowość do popełniania zbrodni (mordów, nowej rabacji) w imię idei braterstwa, czyli przejścia od roli „kata dusz” do roli „kata ciał”, czemu służy skłócanie i dzielenie Polaków. Tego rodzaju supozycji pod adresem Mickiewicza w listach rzymskich (zwłaszcza do Potockiej) odnaleźć można wiele - pojawiają się w opisach od pierwszego do ostatniego ich spotkania. Już 14 lutego Krasiński pisał: „Dziwny duch, taki twardy, taki rewolucjonista w gruncie, a taki despota na powierzchni, taki Konwencją i Piotrem W[ielk]im przepojon, taki sam niewolnik, a taki tyran" ${ }^{24}$. A w końcu marca, gdy opisywał niebywałą aktywność publiczną Mickiewicza w kręgach polskim i włoskim, dodawał komentarze takiego rodzaju: „Najdziksza z potęg przebywa w tym człowieku; zbiera młodych, nic nie wiedzących a poczciwych, zbiera służących, kucharzy, pochlebia im i przeciąga pod władzę swoją. Chce władać, chce carować!"”25. I w następnym dniu: ,niezawodnie nigdym nic piekielniejszego nie znał na ziemi od tego człowieka. Dżengis i Pankracy w nim zharmonizowani. Wszystko zniszczyć i obalić, i swoje postawić - oto popęd, który w nim wiecznie żyw"26. Hrabia podejrzewał, że Legion tworzy Mickiewicz po to, by w Polsce rozpalić rewolucję, szukać odrodzenia narodu przez wewnętrzną wojnę.

Ten człowiek ma się w głębi serca i ducha za kata posłanego z góry, aby karać świat. Wszystko, co August pojmuje miłosiernie i kryształowo, on pojmuje krwawo, mistycznie, obrzydliwie [...]. Jest opętanie w tym wszystkim, bo jest chytrość, fałsz, podstęp, kłamstwo wieczne, okrucieństwo, a przy tym niesłychana potęga, jednak na imię Chrystus zawsze ócz spuszczanie i tchórzostwo moralne, jak u czartów. To Pankracowie wszystko. [...] Co tu się dzieje w duchach ludzkich, nie wyobrazisz sobie; wszyscy Polacy się kłócą, rozbrat i miecz przyniósł im Mickiewicz! ${ }^{27}$

\footnotetext{
${ }^{23}$ Z. Krasiński, Listy do Delfiny Potockiej, t. 3, s. 659 (list z 14 lutego 1848 r.).

${ }^{24}$ Ibidem.

${ }^{25}$ Ibidem, s. 767 (list z 27-28 marca 1848 r.).

${ }^{26}$ Ibidem, s. 770 (list z 29-30 marca 1848 r.).

${ }^{27}$ Ibidem, s. 776-777 (list z 31 marca 1848 r.).
} 
Skład zasad zakwestionował Krasiński nie z powodu (jak twierdził) idei tam wyłożonych, ale z racji przekonania, że to projekt niemożliwy do realizacji bez wielkiego konfliktu, że manifest ten, może i szlachetny w intencjach, stać się musi zarzewiem narodowego dramatu, dziejowego piekła.

Manifest swój przyniósł p. Ad[am] wczoraj z 15 punktów, które jako słowa są niebem na ziemi, a jako czyn mogłyby się przekręcić w piekło na ziemi; między innymi obywatelstwa wszystkie prawa nadane kobietom, każda rodzina chłopska gruntem uposażona własnym, każda gmina gruntem gminnym, wspólnym. Polska dłoń podaje Rusowi i Czechowi, i całej Słowiańszczyźnie. Ewangelia staje się prawem politycznym i społecznym Polski, na pomoc każdemu chrześcijańskiemu ludowi uciśniętemu Polska zawżdy bieży, słowem jakbyś Przedświt zamieniła w kodeks. Powtarzam - jako słowa na papierze to niebo, jako wykonanie może być piekłem, to zależy od wykonania! Pod tym wszystkim coś leży, jest jakaś krętanina ${ }^{28}$.

Owo „coś”, to skrywany plan zniszczenia szlachty, o czym jeszcze będzie mowa. Grzech pychy i wybuchy nienawistnych emocji („Miasto natchnień - czuć wścieklizne”") - te czynniki także wielokrotnie wpisywane były w Mickiewiczowski portret. Widać je w cytatach przywołanych powyżej, a przykłady można by zwielokrotnić. Tu przytoczone zostaną dwa tylko, na zasadzie części za całość. W liście do Delfiny, już po rzymskim pożegnaniu z wyruszającym na front włosko-austriacki twórcą Legionu, nakreślił Krasiński obraz „najniebezpieczniejszego z ludzi”:

Niezawodnie w gruncie ten ryczący czasem tygrys ma serce pełne niepewności. Pycha je nadyma, a źdźbło słomy napotkane na drodze obala, w godzinę znów pycha podnosi i nadzieja, że Towiański posłannikiem z góry, aż znów w kwadrans przychodzi mu do myśli, że on się czartowi oddał i że zaginie duszą w piekle. Z takich żywiołów złożony ten człowiek i on szczerze jest najprzewrotniejszym i stąd też najniebezpieczniejszym z ludzi ${ }^{29}$.

A w liście do Adama Sołtana, pisanym w końcu lipca 1848 roku, hrabia starszego przyjaciela już nie tylko „zmoskalił”, jak czynił to z upodobaniem w epistołach do Delfiny, ale wręcz „spiekielnił”:

[...] szatańska postać koło mnie w owych dniach była. Towiańszczyzny wyobraziciel, a tow[iańszczy]zna niczym innym, jeno R[zeczpospo]litą Czerwoną, odzianą w mistycyzmu barwy. I ta postać (imiennik Twój, Adam, Improwizacji autor, dawny kochanek nasz) rozkrajała mi swymi kłamstwami i ohydnym okrucieństwem, i szałami wnętrzności ${ }^{30}$.

${ }^{28}$ Ibidem, s. 791-792 (list z 5 kwietnia 1848 r.).

${ }^{29}$ Ibidem, s. 805 (list z 10 kwietnia 1848 r.).

${ }^{30}$ Z. Krasiński, Listy do Adama Soltana, oprac. Z. Sudolski, Warszawa 1970, s. 537 (list z 28 lipca 1848 r.). 
I wreszcie sprawa szczególnie drażliwa - podjęta tylko w jednym liście do Potockiej - kwestia anihilacji polskości i wyniszczenia szlachty. W celu unaocznienia tego zagadnienia warto najpierw przytoczyć szczególnie mocny i zarazem tajemniczo niedopowiedziany passus z psalmu:

Tu Sybiry mroźne

I Iwany Groźne -

A po drugiej stronie

Klubowe tyrany,

Kule strute - kwas siarczany -

Ludożercze bronie!

Boże! zmiłuj się nad wami!

Między dwiema szkaradami

Wstać ma Polska kojarznicą!

Dwóch barbarzyństw - ma być spojem -

I to zwiecie - Tajemnica -

To - wieków pokojem!

$\mathrm{W}$ jedno zło jedyne

Wszetecznym poswatem

Siostrę giliotynę

Ślubić z knutem bratem!

Rozdeptać kościoły,

Pomieszać plemiona,

Sumienia anioły

Wygnać z ludzi łona!

I mieć Polskę - tego dzieła

Czarną spełnicielką!

W krew truciznę jej lać wszelką,

By sprawy się jęła! ${ }^{31}$

Czy którykolwiek polski obóz polityczny lub znany i aktywny polityk (ideolog) w realiach 1848 roku głosił takie hasła? - skojarzenia tyranii rewolucyjnej $\mathrm{z}$ caryzmem, terroru powszechnego z domyślnym wygubieniem szlachty (gilotyna i knut), wreszcie zniszczenia chrześcijaństwa i „pomieszania plemion”, czyli likwidacji narodowości. Nawet z broszury Henryka Kamieńskiego, która sprowokowała hrabiego do napisania pierwszego cyklu Psalmów przyszłości, takiego stopu radykalnych idei wydobyć się nie da. Otóż poglądy dokładnie tego rodzaju, wedle Krasińskiego, miał w jego salonie rzymskim wygłosić (a właściwie wykrzyczeć) Mickiewicz, i to przy świadkach (Elizie Krasińskiej, Małachowskim, Norwidzie) - tu trzeba przytoczyć dłuższy cytat z listu - słynnego, wielokrotnie komentowanego - do Potockiej, pisanego przez dwie doby, 20 i 21 marca 1848 roku:

\footnotetext{
${ }^{31}$ Z. Krasiński, Dzieła literackie, t. 1, s. 244.
} 
Polski nie będzie już. Połączą się Czechy, Moskale, Polacy. Wszystko spłynie w jedność plemienia. Narodowości zaginą, stopią się. Zachodnia, łacińska ogłada, przeciwsłowiańska, przeklętą. Rzymski język, rzymska literatura, podobno że i kościół, odrzuconymi, tym samym i wszelki, który przeszłości polskiej chowa tradycję, odrzuconym jest. Szlachta polska to najeźdźcy, to plemię Lezgów przybyłe z Kaukazu - przed wiekami ujarzmiło chłopa Słowianina. Dziś ono plemię obce, ona szlachta musi się rozsypać, zaginąć, zniknąć. Chłop słowiański rozumniejszy w swojej ciemnocie, niż wszystkie filozofy i wszystkie kościoły świata. Wszelka przeszłość herezją, wszelka tradycja, jeśli nie pogańska, grzechem. Imię Polska nawet skazane na śmierć i zagubę. Będzie tylko Słowiańszczyzna. Może to gorzkim, ale taka wola Boża, takie objawienie jej. Gorzkie przecież ojczyźnie było i chrześcijaństwo! a kto zwyciężył? Otóż teraz drugie, a zesilnione podwójnie chrześcijaństwo objawia się światu. Słowian obiera swymi wyczynnikami. Szlachta, w której tkwi podanie ojczyzny i stosunek z Zachodem, musi, musi wykorzeniona być. Wszystko, co tylko było, musi przestać być. Chłopi i nad nimi duchy towiańczyków w hierarchii jakiejś magicznej, teokratycznej oto przyszłość świata, oto zbawienie, oto życie! $!^{32}$

Przez pryzmat tej wypowiedzi, przypisanej Mickiewiczowi, wywód z zacytowanego powyżej fragmentu psalmu staje się jednoznacznie jasny, pozwala nadać ostateczny sens takim zwrotom jak: „rozdeptać kościoły” („kościół [...] odrzuconym jest", czyli usunięcie duchowieństwa katolickiego z przestrzeni wspólnoty?), „pomieszać plemiona” (czyli roztopić Polskę w Słowiańszczyźnie, „wszystko spłynie w jedność plemienia”) czy „, to zwiecie Tajemnicą” (hierarchia mistyczno-teokratyczna, złożona z ludu i towianistycznej władzy, a więc po wygubieniu szlachty, co objaśnia metaforę „ślubienia” gilotyny z knutem, metody rewolucyjnej z caryzmem). Mickiewicz miał te słowa wypowiedzieć podczas zapalczywej polemiki, „wśród niepowstrzymanego rozwścieklenia się na szlachtę" (dalej pisze Krasiński: „Poczułem Pankracego, ale hr. Henryk zachował spokój i tym spokojem, a godnością i przestroga poważną, rozbił wściekłość przeciwnika" ${ }^{33}$ ). Z punktu widzenia genezy Psalmu żalu drugorzędne znaczenie ma fakt, czy Krasiński w tym liście napisał prawdę i dokładnie odtworzył słowa Mickiewicza - w co można wątpić, bowiem żaden ze świadków (poza hrabią) tak sensacyjnej wypowiedzi twórcy Legionu nie zapisał na goraco (a zachowały się z tego czasu listy Krasińskiej i Norwida), ani też nie przywołał po latach. Nie nawiązał też do niej w żaden sposób sam Krasiński w lipcowej epistole do Mickiewicza (liście rozrachunkowym przecież), ani później w korespondencji choćby z Małachowskim-świadkiem czy Cieszkowskim, przed którym nie miał tajemnic $^{34}$. Tego rodzaju poglądów nie wypowiedział Mickiewicz w żadnej innej

${ }^{32}$ Z. Krasiński, Listy do Delfiny Potockiej, t. 3, s. 753-754.

${ }^{33}$ Ibidem, s. 754.

${ }^{34}$ Szczegółowo sprawę (nie)prawdopodobieństwa takiej wypowiedzi Mickiewicza rozpatrywałem w książce pt. Rosja Krasińskiego. Rzecz o nieprzejednaniu, w rozdziale „Zmoskalenie” Adama. Wokót rzymskiego sporu Krasińskiego i Mickiewicza (Poznań 2005). 
zanotowanej deklaracji publicznej w owym czasie, a Skład zasad zaprzecza prawie każdemu zdaniu z tej relacji. Powątpiewał w jej rzetelność Stanisław Pigońn ${ }^{35}$, o konsekwentnym demonizowaniu i wykoślawianiu poglądów Mickiewicza pisali m.in. Alina Witkowska i Zbigniew Sudolski ${ }^{36}$. Jedynie Wiktor Weintraub przyjął, że Krasiński wiernie powtórzył tu słowa Mickiewicza, ale zarazem zaznaczył, że była to swego rodzaju prowokacja ze strony podenerwowanego wieszcza, który w ferworze polemiki miał posłużyć się poglądami Bakunina wyrażonymi w Odezwie do Słowian (znanej też Krasińskiemu, można więc równie dobrze uznać, że to Krasiński poglądy Bakunina włożył w usta Mickiewiczowi) ${ }^{37}$. Niewątpliwie w tej wypowiedzi zbiegły się w jeden węzeł prawie wszystkie lęki i obsesje polityczne, które w pierwszym roku Wiosny Ludów żywił Krasiński. Składały się na nie wizje rozchwiania Polski i Europy przez społeczne rewolty, które wykorzysta do podboju kontynentu Rosja (widziana wtedy jako apokaliptyczna Bestia; małą Bestią, pomocnikiem wielkiej, stał się wtedy dla niego towianizm), wizje mordu szlachty przez lud, zlania się narodów w jeden barbarzyński byt, wreszcie zniszczenia chrześcijaństwa. Ważne z punktu widzenia genezy Psalmu żalu jest to, iż taki zbiór radykalnych deklaracji hrabia przypisał właśnie Mickiewiczowi (czyli chciał widzieć w nim reprezentanta takiego stylu myślenia, a przynajmniej chciał, by w takiej „pozie” ujrzała go Potocka) i potem, bez imiennego oznaczenia, powtórzył w psalmie jako projekcję głosu polskiego „my”/,,ja” rewolucyjnego. I to tak spreparowanemu rewolucyjnemu Mickiewiczowi-biesowi przeciwstawił finalne przesłanie o Polsce - „Bogumile”, która „wzgardziła” „Czerwonym sztandarem/ I moskiewskim carem”38, przesłanie,

${ }^{35}$ Pisał Pigoń w komentarzu do tej relacji: „Może zachodzić wątpliwość, czy Krasiński nie pomieszał tu autentycznych wypowiedzi Mickiewicza z pojęciami, jakie w egzageracji swojej urobił sobie o programie społecznym towianizmu"; Adama Mickiewicza wspomnienia i myśli, zbiór i oprac. S. Pigoń, Warszawa 1958, s. 548.

${ }^{36}$ Sudolski trafnie zauważył: „Im większą aktywność polityczną przejawiał wówczas Mickiewicz, tym w świadomości Krasińskiego zacierała się coraz bardziej zdolność do obiektywnej oceny jego poglądów i działalności”; Krasiński. Opowieść biograficzna, Warszawa 1997, s. 426. Z kolei Witkowska stawiała tezę, że „Krasiński na swój sposób deformował Mickiewicza. Jego styl pisania o ludziach mu światopoglądowo niemiłych jest podobny i czyni ich podobnymi do siebie"; A. Witkowska, op. cit., s. 263. Do ostatniej uwagi wypada jednak dodać, że w 1848 r. żaden inny portret epistolograficzny nie był równie zradykalizowany, jak ten przedstawiający Mickiewicza.

${ }^{37}$ Dowodził Weintraub: „w ogniu walki, Mickiewicz uderzył w Krasińskiego najstraszniejszą ideologią polityczną, jaką znał: ideologią polityczną Bakunina. [...] Okazuje się więc, że ta światoburcza, panslawistyczna tyrada Mickiewicza była wyrazem nie tyle jego poglądów, co stanu emocjonalnego. Posłużył się ideami Bakunina, bo poprzez nie mógł dać wyraz oburzeniu na Krasińskiego, jego konserwatyzm, obawy, brak wiary w rewolucję"; W. Weintraub, Mickiewicz Bakunin, „Kultura Paryska” 1949, nr 8, s. 45-46.

${ }^{38}$ Finalny manifest Krasińskiego miał jednoznaczny, tyleż wizyjno-idealistyczny, co i publicystyczny charakter i w niewielkim stopniu respektował ówczesne polityczno-dziejowe realia: „- Zwiesz się: - Bogumiła - / Czerwonym sztandarem / I moskiewskim carem / Zarównoś wzgardziła! / Od dwóch tych zatracicieli / Tak czarno w Europie! / Wśród nawałnic - na potopie / 
które miało być (także) powtórzeniem wezwania z ich ostatniej rzymskiej rozmowy, „by siał miłość, nienawiści nie krzewił”39.

Jedna rzecz zatem wydaje się dowiedziona: bliskie pokrewieństwo argumentów (a w wielu przypadkach tożsamość) używanych w sporze z Mickiewiczem w 1848 roku i w antyrewolucyjnych tyradach zapisanych w psalmie wskazuje, że to w trakcie rzymskich debat Krasiński dopracował system zarzutów wobec zwolenników europejskich ruchów wolnościowo-rewolucyjnych oraz zbiór idei historiozoficzno-politycznych, poprzez które w tym tekście opisze położenie Polski i świata w dobie Wiosny Ludów. A to spostrzeżenie pozwala na przyjęcie założenia o wpisaniu kryptoportretu Mickiewicza, postrzeganego jako sojusznik „czerwonego sztandaru”, w porządek świata przedstawionego Psalmu żalu.

4.

Edward Balcerzan napisał w Kręgach wtajemniczenia, odnosząc się do ścierania się różnych obiegów recepcyjnych dzieła literackiego, które są wynikiem nierówno rozłożonych wśród odbiorców możliwości rozumienia treści i sensów zawartych w utworze, iż „Bilet wstępu do kręgu wtajemniczonych - wyróżnia”40. Kręgów wtajemniczenia w rozpoznawanie mechanizmu aluzji personalno-światopoglądowych zakodowanych w Psalmie żalu wyróżnić można kilka i to autor największy miał wpływ na ich ustanawianie. Najszerszy zbiór odbiorców winien był zrozumieć generalną zasadę portretowania świata rewolucji i sposób prowadzenia z nim polemiki oraz ideę niepokalanej Polski jako zbawicielki świata w czasach rewolucyjnej smuty (a że wyłożył tę ideę w sposób nieskomplikowany, mógł liczyć na rozległy rezonans). Krąg węższy, ale całkiem liczny, składał się z czytelników znających Odpowiedź na „Psalmy przyszłości” (z bezpośredniej lektury krążących odpisów lub ze słyszenia - dla tych drugich Krasiński we wstępie do Psalmu żalu dokonał streszczenia Odpowiedzi, bez wymieniania nazwiska twórcy). Ów krąg miał zrozumieć niuanse sporu o istotę Ducha dziejów ze Słowackim. W obręb najwęższego kręgu, najbardziej elitarnego, wchodziły osoby w 1848 roku najbliżej związane z Krasińskim lub też bardzo dobrze orientujące się w realiach polskich sporów w początkach Wiosny Ludów. Do grona tego zaliczał się też sam Mickiewicz i ci z kręgu jego znajomych, którym zechciał

Jedna świecisz w bieli! [...] Idź, o Polsko - idź, Aniele / W promienistym ciele! / Świat nie poznał ciebie z lica - / Świat cię zabił - aż na mękę / Sam jest wzięty - a ty rękę / Dasz mu - jego męczennica! / Idź, o Polsko - idź, Aniele / W promienistym ciele! / W tobie Ludzkość przechowana! / Ponad złości i nad szały, / Ponad hańby i nad kały - / Tyś niepokalana!”; Z. Krasiński, Dzieła literackie, t. 1, s. 248.

${ }^{39}$ Z. Krasiński, Listy do Delfiny Potockiej, t. 3, s. 805.

${ }^{40}$ E. Balcerzan, Kręgi wtajemniczenia, „Teksty” 1978, nr 4, s. 6; tytułowemu zjawisku autor poświęcił znakomitą monografię; vide E. Balcerzan, Kręgi wtajemniczenia. Czytelnik, badacz, thumacz, pisarz, Kraków 1982. 
objaśnić swoje miejsce w świecie przedstawionym poematu (jeśli takowi byli). Tacy czytelnicy z systemu aluzji mogli wyłuskać ukrytą batalię $\mathrm{z}$ „wieszczem starym”, dojrzeć w Psalmie żalu próbę definitywnego zamknięcia owej „rzymskiej gigantomachii”, a nawet pomyślnego dla siebie rozstrzygnięcia trój-antagonizmu wieszczów. Dzięki takiemu rozwiązaniu sporu projekcja historiozoficzna Krasińskiego i ukryte za nią idealistyczno-konserwatywna wizja narodu (oparta na porządku etnocentrycznym) oraz antyrewolucyjna koncepcja politycznego nieangażowania się $w$ burzliwe wydarzenia europejskie byłyby ostatnim słowem w tej trój-polemice. Nie ulega wątpliwości, że sporu z Mickiewiczem w opisie genezy Psalmu żalu pomijać nie można.

\section{Bibliografia}

Adama Mickiewicza wspomnienia i myśli, zbiór i oprac. S. Pigoń, Warszawa 1958.

Balcerzan, Edward, Kregi wtajemniczenia, „Teksty” 1978, nr 4.

Balcerzan, Edward, Kręgi wtajemniczenia. Czytelnik, badacz, ttumacz, pisarz, Kraków 1982.

Baszkiewicz, Jan, Historia Francji, Wrocław 1999.

Bieńkowska, Ewa, Rzym 1848, „Znak” 1974, nr 10.

Dautry, Jean, Historia rewolucji i kontrrewolucji we Francji w latach 1848-1851, Warszawa 1950.

Fabianowski, Andrzej, Myśl polityczna Zygmunta Krasińskiego, Ciechanów 1991.

Fiećko, Jerzy, „Zmoskalenie” Adama. Wokót rzymskiego sporu Krasinskiego i Mickiewicza, w: idem, Rosja Krasińskiego. Rzecz o nieprzejednaniu, Poznań 2005.

Fiećko, Jerzy, Krasiński przeciw Mickiewiczowi. Najważniejszy spór romantyków, Poznań 2011.

Fiećko, Jerzy, Stowacki wedtug Krasińskiego, w: Jaki Stowacki? Studia i szkice w dwusetna rocznicę urodzin poety, red. E. Grzęda, M. Ursel, Wrocław 2012.

Janion, Maria, Dialektyka historii w polemice między Stowackim i Krasińskim, w: eadem, Prace wybrane, red. M. Czermińska, t. 2, Kraków 2000.

Kallenbach, Józef, Towianizm na tle historycznym, Kraków 1924.

Karpiński, Wojciech, Dalekie i bliskie, „Twórczość” 1976, nr 5.

Kleiner, Juliusz, Zygmunt Krasiński. Dzieje myśli, Lwów 1912, t. 1-2.

Kowalczykowa, Alina, Poglady filozoficzne Zygmunta Krasińskiego, w: Polska myśl filozoficzna i społeczna, red. A. Walicki, t. 1, Warszawa 1973.

Kowalczykowa, Alina, Stowacki, Warszawa 1994.

Krasiński, Zygmunt, Listy do Adama Sołtana, oprac. Z. Sudolski, Warszawa 1970.

Krasiński, Zygmunt, Listy do Konstantego Gaszyńskiego, oprac. Z. Sudolski, Warszawa 1971.

Krasiński, Zygmunt, Dzieła literackie, oprac. P. Hertz, Warszawa 1973, t. 1-3.

Krasiński, Zygmunt, Listy do Delfiny Potockiej, oprac. Z. Sudolski, Warszawa 1975, t. 1-3. Krasiński, Zygmunt, Listy do Augusta Cieszkowskiego, Edwarda Jaroszyńskiego, Bronistawa Trentowskiego, oprac. Z. Sudolski, Warszawa 1988, t. 1-2. 
Krasiński, Zygmunt, Listy do różnych adresatów, oprac. Z. Sudolski, Warszawa 1991, t. 1-2. Kridl, Manfred, Antagonizm wieszczów. Rzecz o stosunku Stowackiego do Mickiewicza, Warszawa 1925.

Kubale, Anna, Dramat bólu istnienia w listach Zygmunta Krasińskiego, Gdańsk 1997. Liebfeld, Alfred, Napoleon III, Warszawa 1979.

Luna, Frederick de, The French Republic under Cavaignac, 1848, Princeton N.J. 1969. Markiewicz, Henryk, Rodowód i losy mitu trzech wieszczów, w: idem, Świadomość literatury. Rozprawy i szkice, Warszawa 1985.

Mickiewicz, Adam, Dzieła. Wydanie rocznicowe, t. 12: Legion Polski. Trybuna Ludów, red. S. Kieniewicz, Warszawa 1997.

Mickiewicz, Adam, Dzieła. Wydanie rocznicowe, t. 16: Listy. Część trzecia 1842-1848, red. M. Dernałowicz, E. Jaworska, M. Zielińska, Warszawa 2004.

Mickiewicz, Adam, Dzieła. Wydanie rocznicowe, t. 17: Listy. Część trzecia 1849-1855, red. M. Dernałowicz, E. Jaworska, M. Zielińska, Warszawa 2005.

Słowacki, Juliusz, Dzieła wszystkie, red. J. Kleiner, t. 7, Wrocław 1952.

Słowacki, Juliusz, Wiersze. Nowe wydanie krytyczne, red. J. Brzozowski, Z. Przychodniak, Poznań 2005.

Sudolski, Zbigniew, Zygmunt Krasiński, Warszawa 1974.

Sudolski, Zbigniew, Słowacki w oczach Krasińskiego. Z dziejów wzajemnych kontaktów, „Rocznik Towarzystwa Literackiego im. Adama Mickiewicza” 1979/1980.

Sudolski, Zbigniew, Krasiński wobec roku 1848, w: Romantycy i rewolucja, red. A. Kowalczykowa, Wrocław 1980.

Sudolski, Zbigniew, Krasiński. Opowieść biograficzna, Warszawa 1997.

Szczeglacka, Ewa, Romantyczny homo legens. Zygmunt Krasiński jako czytelnik polskich poetów, Warszawa 2003.

Tomaszewska, Grażyna, Mickiewicz - Krasiński. O wyobraźni utopijnej i katastroficznej, Gdańsk 2001.

Weintraub, Wiktor, Mickiewicz-Bakunin, „Kultura Paryska” 1949, nr 8.

Witkowska, Alina, Mickiewicz. Słowo i czyn, wyd. 4 zmienione, Warszawa 1998.

JERZY FIEĆKO, urodzony w 1960 r., prof. dr hab., historyk literatury w Instytucie Filologii Polskiej Uniwersytetu Adama Mickiewicza, autor pięciu monografii: Rosja, Polska i misja zesłańców. Syberyjska twórczość Agatona Gillera (1997); Rosja Krasińskiego. Rzecz o nieprzejednaniu (2005); Krasiński przeciw Mickiewiczowi. Najważniejszy spór romantyków (2011); Katastrofizm, ateizm i inne obrachunki. Szkice o ideach polskich romantyków (2015); Romantycy i polityka. Szkice historyczno-literackie (2016). Redaktor i współredaktor dziewięciu książek naukowych. Opublikował ponad 130 rozpraw i artykułów (poświęconych głównie literaturze XIX w.) w książkach zbiorowych i periodykach naukowych. 